\title{
Limits of GIS implementation in secondary education
}

\author{
Veronika Bernhäuserováa $^{\mathrm{a}}$ *, Lenka Havelková ${ }^{\mathrm{b}}$, Martin Hanus ${ }^{\mathrm{c}}$ \\ ${ }^{a, b, c}$ Centre for Geographical and Environmental Education, Department of Social Geography and Regional \\ Development, Faculty of Science, Charles University, Albertov 6, 12800 Praha 2, Czech Republic, \\ veronika.bernhauserova@natur.cuni.cz. \\ * Corresponding author
}

Keywords: Geographic Information Systems, GIS, implementation, geography education, systematic review, PRISMA

\begin{abstract}
:
The potential of geographic information systems (GIS) is found as very significant for geography and cartography education. Previous research showed that teaching with GIS can help students foster many (not only map and geographic) skills. The most frequently mentioned benefit of learning with GIS in geography lessons is the development of spatial thinking. Because GIS helps students to obtain, process, analyze, evaluate, and present information related to a specific area (Bednarz, Schee 2006; Lee, Bednarz 2009; Kerski et al. 2013; Král, Řezníčková 2013; Jo et al. 2016). Other frequently cited benefits of learning with GIS are developing of critical thinking and the potential use of GIS in problembased learning (Rød 2010; Uuemaa, Liiber 2014; Jo et al. 2016). Despite advantages of teaching and learning with GIS, its implementation in schools is still rather sporadic in a considerable number of countries (Demirci 2009; Král, Řezníčková 2013).
\end{abstract}

Considering the prevailing insufficient use of GIS during teaching, a systematic review was carried out to identify and categorize the most common and serious limits of GIS implementation in teaching.

Specifically, the aim of the review is to answer the following questions:

- Based on previous empirical research, what are the main limits for and barriers to using GIS in teaching?

- Does perception of limits change over time?

- Is perception of limits different among various actors in education (pupils, teachers, curriculum developers ...).

- Does the perception and occurrence of limits vary between specific geographical areas?

The identified limits, their categorization, and analysis are the key steps leading to their elimination, and thus it can lead to more frequent and more accessible use of GIS in teaching.

The systematic review is methodologically grounded in the Preferred Reporting Items for Systematic Reviews and MetaAnalyzes (PRISMA), i.e., an explicit systematic method for identifying, evaluating, and synthesizing relevant results (Moher et al. 2009). Due to the topic of systematic review (education, teaching) the Web of Science (WoS) and Education Resources Information Center (ERIC) databases were selected for searching for relevant peer-reviewed articles (similarly also Havelková, Hanus 2019).

In the next few lines the used methodology is described. First of all, it was necessary to search for relevant articles in the selected databases, this part of PRISMA methodology is called the identification. Based on the previous research about GIS in education, the search command was created (see Figure 1). The search command used Boolean operations. The first part of the command is connected to the definition of GIS, and the second part to the teaching. This command has been inserted into the selected databases. After removing duplicates, a database containing 2,851 records in total was created based on this command.

Additional selection criteria were applied for the first screening. If, on the basis of the abstract, the article was evaluated as not meeting the given criteria, it was excluded from the database. A total of nine criteria were included in this selection. These criteria were:

- $G I S$ - the article had to be about GIS. In this study the term GIS included, e.g., geoportals, Google Earth, StoryMaps, ArcGIS, etc.

- GIS in education - the article had to be about GIS use in education. Moreover, there had to be presented or tested cognitively demanding skills (to not use GIS similarly as a static map, i.e., to exploit the specific educational potential of GIS).

- Student - the participants had to be primary or secondary school students, pre-service teachers or in-service teachers in primary or secondary school.

- Special populations - the article had not to be dedicated to special parts of the population, such as students with special educational needs.

- Empirical research - the article had to be empirical research with a clearly defined methodology (not, for example, lesson description) and had not to be a review.

- Peer-review - the article had to be peer-reviewed. 
- Limits and barriers - the article was eliminated when it was clear from abstract that it was not dealing with limits for / barriers to GIS implementation in education.

- English - the article had to be written in English.

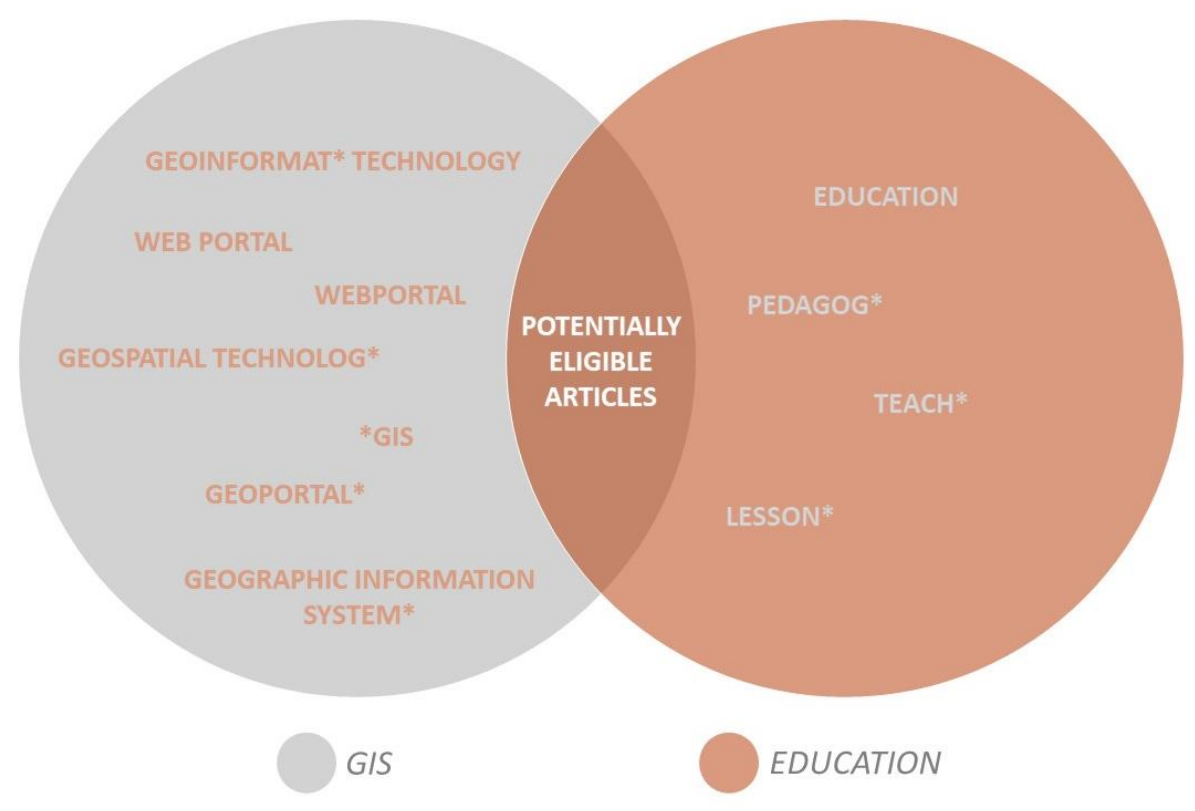

Figure 1. Keywords used at search command

Two evaluators independently performed this screening of abstracts based on the selected criteria. The total of 223 potentially relevant articles remained in the database. The full-texts of these articles were subsequently obtained and subjected to a more specific evaluation, the so-called eligibility. Eligibility was performed by three evaluators, where one article was always evaluated by two of them, and there had to be unanimity. Most of the evaluated articles focus on the effectiveness of GIS usage in terms of skills development or knowledge acquisition and address the desired limits only marginally or not at all. However, articles that deal specifically with the limits of GIS implementation in teaching, most often from teachers' point of view, were found as well.

The specific results of the employed systematic review will be the key part of the presented conference contribution. Except the answers to the main, aforementioned, research questions, the recommendations related to how a suitable GIS course for students, pre-service teachers, or a follow-up course for in-service teachers should be developed will be stated based on the review results.

\section{References:}

BEDNARZ, S. W. \& SCHEE, J. V. D. (2006): Europe and the United States: The implementation of geographic information systems in secondary education in two contexts. Technology, Pedagogy and Education, 15(2), 191-205.

DEMIRCI, A. (2009): How do teachers approach new technologies: Geography teachers' attitudes towards Geographic Information Systems (GIS). European Journal of Educational Studies, 1(1), 43-53.

HAVELKOVÁ, L. \& HANUS, M. (2019): Map skills in education: A systematic review of terminology, methodology, and influencing factors. Review of International Geographical Education Online, 9, 2, 361-401.

JO, I., HONG, J. E. \& VERMA, K. (2016): Facilitating spatial thinking in world geography using Web-based GIS. Journal of Geography in Higher Education, 3, 40, 442-459.

KERSKI, J. J., DEMIRCI, A. \& MILSON, A. J. (2013): The Global Landscape of GIS in Secondary Education. Journal of Geography, 112(6), 232-247.

KRÁL, L. \& ŘEZNÍČKOVÁ, D. (2013): Rozšíření a implementace GIS ve výuce na gymnáziích v Česku. Geografie, $188(3), 265-283$.

LEE, J., \& BEDNARZ, R. (2009): Effect of GIS learning on spatial thinking. Journal of Geography in Higher Education, 33, 183-198.

MOHER, D., LIBERATI, A., TETZLAFF, J., \& ALTMAN, D. G. (2009): Preferred reporting items for systematic reviews and meta-analyses: the PRISMA statement. Annals of internal medicine, 151(4), 264-269.

RØD, J. K., LARSEN, W. \& NILSEN, E. (2010): Learning geography with GIS: Integrating GIS into upper secondary school geography curricula. Norsk Geografisk Tidsskrift - Norwegian Journal of Geography, 1, 64, 21-35

UUEMAA, E., \& LIIBER, Ü. (2014): The Experience of Using Geoportal in National Geography Olympiad in Estonia, In: Geospatial Innovation for Society, 328-331. 